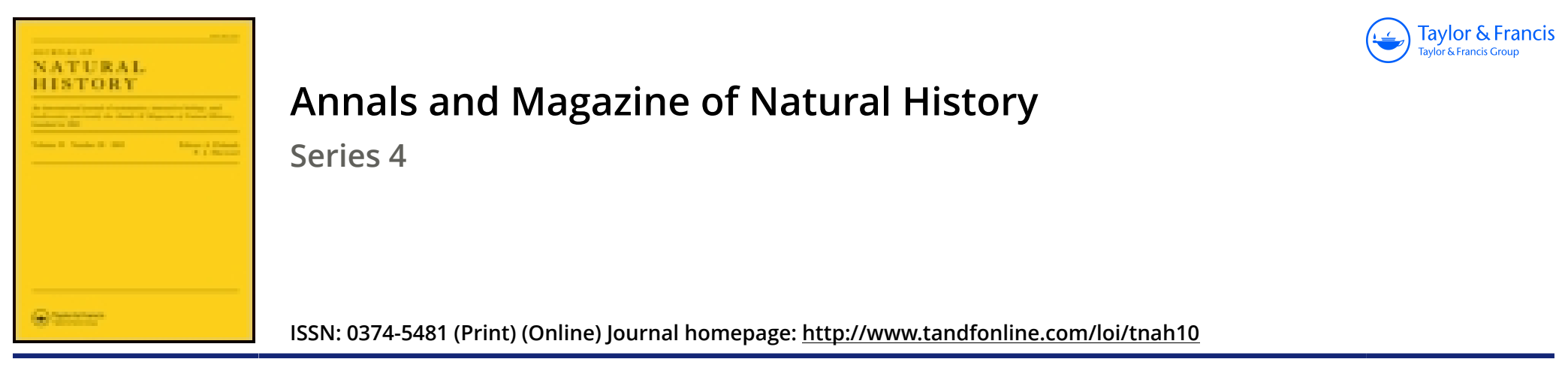

\title{
On Häckel's theory (Allœogenesis) of the genetic connexion between the Geryonidæ and ÆEginidæ
}

\section{Alexander Agassiz}

To cite this article: Alexander Agassiz (1876) On Häckel's theory (Allœogenesis) of the genetic connexion between the Geryonidæ and Æginidæ, Annals and Magazine of Natural History, 17:102, 481-481, DOI: $10.1080 / 00222937608681995$

To link to this article: http://dx.doi.org/10.1080/00222937608681995

Published online: 15 Oct 2009.

Submit your article to this journal $₫$

Џ Article views: 3

Q View related articles ๘ 
On Häckel's Theory (Alloogenesis) of the Genetic Connexion lotwien the Geryonidæe and Aginidæ. By Alexander A g.ssiz.

In the Proceedings of the Elliot Society for 1857 M'Crady gave a very interesting account of the commensalism of the young brood of a Cunina and of Turritopsis. No notice was taken of this remarkable mode of development, $\mathrm{M}^{\circ} \mathrm{Crady}$ 's olservations having been discredited by the later publication (1865) of a magnificently illustrated memoir on the "Ruisselquallen" by Häckel. The startling" hypothesis of the genetic connexion between the Geryonidx and Fginidre contained in this memoir, and called by Häckel allœogenesis, has been ever since a stumblingblock to all theories of genetic relationship among Medusæ.

Two short papers recently published-the one by Schulze (Mitt. naturw. Ver. f. Steiermark, 1875, p. 125), and the other by Uljanin (Ann. \& Mag. Nat. Hist. March 1876, p. 215), have, however, proved conclusively that Häckel's theory, like many other of his vagaries, had no foundation of truth. It was based not merely on an incorrect interpretation of facts, but the facts themselves existed only in his imagination.

As, perhaps, with the exception of bis monograph of the Radiolaria, no other memoir has contributed more than the one above quoted to give Häckel the position he holds among zoologists, we may be allowed to remind the Häckelian school of naturalists that this same genetic connexion has furnished the text for many a sermon from their high priest. Infallible himself, he has been unsparing in his condemnation of the ignorance and shallowness of his opponents. Proved now to be in the wrong, we expect therefore justico without mercy from this stern scientific critic, and look forward in the next number of the 'Jenaische Zeitschrift' for a thorough cistigation of Häckel by Häckel, showing up the absurdity of alloogenesis and all that hangs thereby.-Sillimen's American Journal, May 1876.

On the Embryogeny of the Ephemeræ, especially that of Palingenia virgo, Oliv. By M. N. JoLY.

With the exception of the memoir by Luigi Calori "Sulla generazione vivipara della Chloë diptera (E hemesa diptera, Liun.)" ", there is, so far as I know, no work on the embryogeny of the Ephemercet. One might even say that all the acts concerned in the reproduction of these insects are still enveloped in a mysterious veil. Their copulation has been differently described by the authors who have treated of it. Swammerdam even denies that it ever takes place, and thinks that the ora are fecundated by the male liquid 1848 .

* See 'Nuovi Annali delle Scienze Naturali,' ser. 2, tome ix. Bologna,

[ $\dagger$ The author seems to have no knowledge of Sir John Lubbock's paper "On the Development of Chlièm dimidiatum," in the Transactions of the Linnean Society, vols. xxiv. and $\mathrm{xxv},-\mathrm{E} \mathrm{D}$.

Amn. \& Mag. N. Tist. Ser. 4. Tol. xvii. 